Article

\title{
Legacies of Hani Susumu's Documentary School
}

\author{
Marcos P. Centeno Martín (D) \\ Department of Cultures and Languages, School of Arts, Birkbeck, University of London, \\ London WC1E 7HX, UK; m.centeno@bbk.ac.uk
}

Received: 14 May 2019; Accepted: 26 June 2019; Published: 3 July 2019

check for updates

\begin{abstract}
This article seeks to cast light on some of Hani Susumu's theoretical and practical contributions to post-war Japanese documentaries. The article will also show how he created a documentary school at Iwanami Eiga based on authors' closeness to the filmed object. This is crucial in order to understand the tendencies that developed in non-fiction films from the late 1950s. Hani's influence can be seen in the leaders of militant cinema, Tsuchimoto Noriaki and Ogawa Shinsuke, who were trained at Iwanami Eiga. However, some of his theoretical writings, together with his documentary films Hōryüji (1958) and Gunka Ken 2 (1962), reveal how his singular subjective realism is applied to unusual shooting objects, landscapes. This article assesses this lesser-known aspect of Hani's work and its links to certain developments in Japanese documentary films led by other filmmakers, such as Teshigahara Hiroshi and Adachi Masao, which have not yet been addressed.
\end{abstract}

Keywords: Hani Susumu; avant-garde documentary; new Left; Teshigahara Hiroshi; Adachi Masao; subjectivity; landscapes

\section{Introduction}

An approach to Hani Susumu's oeuvre is essential to understand the theoretical discussions and cinematic innovations that took place in postwar Japan. Hani became a leading figure of the Japanese New Wave and an internationally renowned filmmaker, mainly as a result of his feature films Bad Boys (Furyō shonen, 1960), which won the Director's Guild Prize in 1961, She and He (Kanojo to kare, 1963), and, particularly, Nanami: Inferno of First Love (Hatsukoi: Jigoku-hen, 1968), which was nominated for the Golden Lion at the Berlin Film Festival. However, this research focuses on his work as a documentary maker and theorist in the earlier decade, which has been widely neglected by authors. ${ }^{1}$ Hani was one of the five founding members of Iwanami Eiga, a production company that specialized in documentary films, for which he directed twenty-seven medium-length films, made between 1951 and 1962. Alongside this work as a filmmaker, Hani was a prolific author who simultaneously theorized about a singular film-making method and the possibilities of a new cinema through writings that, to date, have not received the attention they deserve.

This article seeks to illustrate how Hani created a documentary school based on the author's extraordinary commitment to the depicted object, which is crucial to understand certain developments in non-fiction film from the late 1950s. ${ }^{2}$ Hani pioneered a kind of subjective realism in non-fiction by discovering a new kind of reality that is available for documentary makers, an inner universe existing in the outer world which could be explored through his method of shooting protagonists who did not act. Thus, Hani breaks with avant-garde authors of the time who prioritized the portrayal of directors'

1 Although, the critic Sato Tadao noted that it was his precursor's character that laid the foundations for the renewal of the cinematic language of the 1960's (Satō 1973, pp. 174-87; Satō 1997, pp. 3-12).

2 This pioneering nature of Hani for the creation of a postwar Japanese documentary school has already been noted (Satō 1970, pp. 373-74; Nornes 2006, pp. 56-89). 
subjectivity, as well as departing from those exclusively concerned with the social reality of their characters. Hani opened up new avenues for the development of documentary practices which proved to be crucial for years to come. To tackle this question, this text first contextualizes Hani's theoretical framework and, secondly, interrogates how his ideas were put into practice, by himself as well as by subsequent documentary filmmakers. The final hypothesis is that the impact of Hani's school can be traced not only to Tsuchimoto Noriaki and Ogawa Shinsuke's works, based on an extreme engagement with the filmed objects, but also through the work of avant-garde documentary makers focusing on landscapes, such as Teshigahara Hiroshi and Adachi Masao. Hani's earlier usage of his filmmaking method to represent landscapes becomes one of the most innovative postwar attempts to develop cinematic subjectivity in unexplored directions.

\section{Contextualizing Hani's Theoretical Contribution}

Hani claimed that while filmmakers should not vanish, they should reduce their predominance and merge with the environment in order to penetrate into the inner universe of their characters. While the debates in which he was engaged from the mid-1950s had a significant repercussion in Japan, his texts have never been translated and are widely unknown in the West. ${ }^{3}$ The first surprising aspect of Hani's work stance is the way it is shaped by multiple transnational references. First, British filmmakers of the 1930s and 1940s were significantly influential, as happened with many other Japanese filmmakers and theorists. Hani met Stuart Legg during his trip to Japan (Hani 1958, pp. 88-120) and praised Grierson, Rotha, Wright, Cavalcanti, and Arthur Elton's depiction of the working class (Hani 1958, p. 118). Second, while Hani does not follow their social concern, he is interested in their humanist tendency, which he also finds in other prior approaches to reality developed during the Spanish Civil War, such as Robert Capa's photography and André Malraux and Ernest Hemingway's literature (Hani 1960, p. 80). Third, Hani also admires the humanism displayed in the work of Robert Flaherty. While Hani acknowledges that he had been undermined by those who criticized that he had not been faithful enough to reality as a result of his staged sequences, it is his approach to the problems of the individual from a human, rather than social, angle where Hani finds a source of inspiration. He commends Nanook of the North (1922) as a pioneering work for its portrayal of the personal dimension of the Eskimo's world (Hani 1972, p. 36). Following the example of this American filmmaker, Hani claims that beauty is neither a result of imitating nature, as Kobayashi Hideo suggested, nor a calculated abstraction, as proposed by Mizuo Hiroshi, but what leads us to an emotional level (Hani 1969, pp. 25-36; 1972, pp. 3-40). ${ }^{4}$

In addition, the theoretical stance developed by Hani cannot be understood without taking into account the debates on realism led by the Iwasaki Akira and Imamura Taihei that had started before the war. According to Imamura, documentary making entails a selection of reality that he defines as shiryō wo toru ("taking a document") during which a non-subjective factual event is captured (Imamura 1954). Imamura's theory is articulated around the notion of "documentary quality" (kirokusei), which seeks to make cinema closer to a pure form of realism (Imamura 1952, p. 112) and revives certain practices from primitive cinema that reject any intervention over the filmed object (Imamura 1940, pp. 80-98). However, Iwasaki was opposed to that apparent capacity of cinema to mirror reality. He engaged in a discussion on the montage theory, criticizes the myth of cinematic objectivity, and raises the problem of fallacy in cinema even stating that "films lie deliberately" (Iwasaki 1956, p. 26). ${ }^{5}$

3 Among those who drew on Hani's ideas are Matsumoto and Matsumoto and Noda (1964), Iijima (1960), and, particularly, Satō $(1971,1977,1997,2010)$.

4 In the discussions about the links between image (eizō) and reality proposed by Hani in late 1960s, Kobayashi claimed that beauty is taken from the external reality, while Mizuo argued that is an artistic construction whose origin is inside the human mind. Kobayashi's text is included in Hani (1999, pp. 164-77) and Mizuo's text in Hani (1969, pp. 113-32).

5 According to Iwamoto Kenji (Iwamoto 1974), Iwasaki introduced the term 'montage' in Iwamoto, Japan. 
Hani's stance inherits Imamura's understanding of cinema as a valid witness to reality, however, he also joins Iwasaki Akira's criticism of Grierson's pretension of objectivity and Rotha's blind confidence in dramatization (Hani 1959a, p. 9; Hani 1972, pp. 33-75). Hani certainly rejects the employment of actors, settings, rehearsals, and scripts in order to film the spontaneous and unpredictable reality. Therefore, despite sharing a background in realism with the British documentary makers, Hani's filmmaking method was not exactly the same. To a great extent, the spread of lighter cameras, such as the Arriflex, allowed filmmakers to implement a new style and gave them further freedom to work without detailed planning.

Indeed, these technical improvements in the second half of the 1950s allowed for the development of new documentary formats, such as the North American direct cinema and the French cinéma vérité, emerging as a response to dramatization in documentary film. One may be tempted to link Hani to these movements, as he shared their naturalist techniques, such as shooting on location with non-professional actors and natural lighting, with them, as well as their necessity to be constantly vigilant about the predetermined judgements and common sense fostered by mainstream cinema. However, none of these Western developments are suitable to accurately define Hani's style. As Nornes (2006, p. 58) stated, they never had an equivalent in Japanese documentary film, as Japanese writers and directors were reluctant to follow them.

Japanese avant-garde documentary linked to the new Left was significantly different from the stance proposed by direct cinema. Japanese authors generally agreed about the need for a filmmaker's presence and self-conscious attitude, understanding that a documentary is merely the shooting of what is observed (Matsumoto [1963] 2005, pp. 66-79). However, Hani's method does not fit completely in a cinéma vérité approach. According to Erik Banouw, while direct cinema brings the camera to a situation of tension and waits for a crisis to happen, Rouch's cinéma vérité triggers a crisis (Banouw [1974] 1996, p. 223). Hani certainly shares Rouch's understanding that a filmmaker's participation entails a subjectivity that is not only unavoidable but also necessary (Hani 1959b, p. 49; 1959c, p. 45). However, his goal is not highlighting the presence of the filmmaker. On the contrary, his method is based on a discreet attitude not aimed at exploring the author's own subjectivity, but that of the characters before the camera (Hani 1956, p. 211). By doing this, Hani inverts the focus in the postwar discussion of subjectivity, shifting the attention from the filming subject (director) to the object (profilmic world).

Hani's writings originated in fact before the direct cinema and cinéma vérité movement. His publications, including film theory, criticism, reviews and interviews, appeared from 1955 until 1967. ${ }^{6}$ His theoretical developments must be contextualized within the discussions taking place within the culture circles that had proliferated in the aftermath of World War II and have been studied recently (Toba 2010, pp. 19-47; Key 2011, pp. 7-34). Avant-garde artists, including Teshigahara Hiroshi, Kōbō Abe, Okamoto Taro, and critic Hanada Kiyoteru, engaged in a quest for new ways to capture reality and sought a renewal of the concept of kiroku-which can be translated as "document" or "documentary" in a wide sense-in literature and other arts. ${ }^{7}$ At the end of the 1950s, these explorations expanded into the film scene, when documentary makers Hani Susumu and Matsumoto Toshio joined the group Genzai no Kai (Contemporary Society). As a result, the group was reorganized into the Kiroku Geijutsu no Kai (Documentary Arts Society) in May 1957 with the notion of documentary as part of the visual culture (Key 2011, p. 13). ${ }^{8}$ The increasing importance of documentary film in these debates is also noticed by Nornes (2006, p. 58), who asserted that Japanese documentary production

6 Although Hani also published on the television (1959-1960), the nature of image, art, and means of communication (1969-1972).

7 As Key (2011, p. 7) noted, realism was at stake from the early literary discussions around artistic innovation of the 1950s, not only because forms unavoidably evolved but also because the understanding and perception of "the real", of which realism is supposed to represent, also changed.

8 For an account on the documentary groups that proliferated in the 1950's and Matsumoto's role in the discussion about subject (shutai) and object (taisho) also see Key (2011, pp. 7-34); Nornes (2007, pp. 19-27), and Raine (2012). 
had increased more than $1000 \%$ from 1946 and that vitality demanded a fresh critical approach to this medium.

To a great extent, this discussion of the avant-garde documentary film was shaped by an ideological and aesthetical rupture in the Left, especially as a result of artists' and intellectuals' rejection of the Soviet repression of the Hungarian Uprising in November 1956. ${ }^{9}$ The result was illustrated by a 1957 debate that Hani Susumu held with the veteran documentary maker Kamei Fumio, published in Kinema Junpō (Hani and Kamei 1957, pp. 40-47). Hani became a representative filmmaker of that "new Left" (shinsayoku), alongside other authors such as Teshigahara Hiroshi and Matsumoto Toshio, who resisted old forms of realism, which were seen as a mark of authoritarianism typical of fascism as well as of Stalinism (Matsumoto 1963, p. 64). Hani criticized Stalinism and the restoration of János Kádár's government throughout several articles written for the journal Chūō kōron after his visit to Hungary and Poland in the end of the 1950s. It is precisely within the Iron Curtain where Hani finds an inspiring reaction against socialist realism. He wrote extensively on Polish directors, such as Andrzej Wajda, Andrzej Munk (Hani 1961a, 1961b, 1961c), and Jerzy Kawalerowicz, (Hani 1959a), whose films surprised him for their personal approach as well as for the way the dealt with political issues (Hani 1961c, p. 245). Throughout these films, Hani finds a "personal criticism", jiko hihan, that anticipates the notions of subjectivity and authorship on which the debates around the new cinemas would be based (Hani 1963, p. 132).

However, the concept of subjectivity (shutaisei) can be quite misleading as its meaning varied depending on who used it. ${ }^{10}$ Even within the new Left, there was no consensus. To Matsumoto, the narrative tradition of documentary film had failed to interrogate the cinematic medium as such, neglecting other potential ways to perceive reality. As a result, backed by Hanada Kiyoteru and Abe Kōbō's theories, he proposed an avant-garde documentary whose aim was to dismantle automatisms of perception through defamiliarizing techniques (Matsumoto [1963] 2005, pp. 253-61). As can be seen in his early shot documentaries Bicycle in Dream (Ginrin, 1955), Security Treaty (Anpo jōyaku, 1960), and The Song of Stone (Ishi no uta, 1963), Matsumoto challenges the apparent image's testimonial nature by dismantling impressions of reality and engages in a discussion about the subject (shutai) and in opposition to the world as taisho (object), although as Raine (2012, p. 146) notes, Matsumoto does not employ the widely used concept of the time, shutaisei, in his essay.

Unlike in Matsumoto, Hani's will for a breakthrough was not incompatible with cinema's role as a witness of reality. After all, if cinema moved away from reality, the chance to discover, which was an essential task for filmmakers, would be neglected (Hani 1958, p. 49). Hani devotes a large number of texts to defending how documentaries should explore the circumstances of the filmed individuals. However, rather than focusing on their external appearance, films should interrogate their internal dimension, often leading to an emotional level. Ironically, this approach to realism does not reject fantastic and imaginary aspects, since they are part of the human being. Like Matsumoto, he does not reduce the reality available to documentary makers to the factual world but also expands their scope to a subjective world, a field that had been considered exclusive to fictional avant-garde up until that point. However, unlike Matsumoto, this interior world portrayed in documentary films should not belong to the author, but rather to the individuals featured on the screen (Hani et al. 1956, pp. 45-52).

Thus, Hani's filmmaking style is grounded on the improvisation of characters who play themselves. Nevertheless, while Hani proposes closeness to reality in which he rejects any absolute control over the filmed object, his works cannot be categorized as observational cinema either. According to Hani, the best way to explore the inner universes of the characters before the camera is to become familiar with them. To that end, documentary makers should work with three kind of "protagonists who do not act" (Hani 1958). The first two are children and animals, who's spontaneous behaviour would

9 Discontent had started to crystallise from the Sixth Congress of the Japanese Communist Party in July 1955, but it intensified as a result of the Soviet intervention in Hungary.

10 Also noted by Nornes (2006, pp. 56-89). 
allow privileged access to instincts, anxieties, and desires alien to filmmakers. This is why Hani spent weeks visiting schools and observing children in his most outstanding works, Children in the Classroom (Kyōshitsu no kodomotachi, 1954) and Children who Draw (E wo kaku kodomotachi, 1956), but also the lesser-known Sōseiji gakyū [Twins Study] (1956) and Gurūpu no shidō [Group Direction] (1956). After that, Hani embarks on an even more daring enterprise, seeking to interrogate the inner universe of animals in Dōbutsuen nikki [Zoo Diary] (1957), for which he spent one year and a half visiting Ueno Zoo in Tokyo. ${ }^{11}$ It is in these documentaries where we can find the hallmarks of a style that Hani developed in the following decade, including improvisation, shooting on location with non-professional actors, rejection of scriptwriting, psychoanalysis, and traumatic pasts. These are the main traits that epitomise not only Hani's most renowned feature films internationally, such as Bad Boys (1960), She and He (1963), Nanami: Inferno of First Love (1968), and Aido: Slave of Love (1969), but also the early developments the Japanese New Wave in the 1960s.

During the following years, a sort of radical version of Hani's documentary was somehow developed by two leading figures of the Japanese militant documentary cinema, Tsuchimoto Noriaki and Ogawa Shinsuke, who were trained at Iwanami Eiga in early 1960s. ${ }^{12}$ Both followed Hani's stance based on familiarizing with the portrayed objects on screen, but also added an extreme commitment to the topics they depicted. Tsuchimoto, who joined Iwanami Eiga in 1956 after watching Children Who Draw, caused a great impact on him (Gerow and Noriaki 2014) and became Hani's assistant director for Bad Boys (Furyo shonen, 1960). For almost a decade, between 1965 and 1974, Tsuchimoto visited Minamata village, where he made a series of documentaries on Minamata disease, following peasants seeking compensation for the poisoning of thousands of people by mercury spilled into the water. The close relationship between Minamata victims and Tsuchimoto is illustrated by Inoue (2019) and the way Tsuchimoto adopts Hani's theoretical and methodological framework is assessed by Jesty (2019), both in this Special Issue.

However, Ogawa is an even a more radical example of this closeness between filmmakers and environment, to the extent that they merge in his films and become indissolubly linked. In 1968, Ogawa founded Ogawa Productions and travelled to Sanrizuka with his team, where they ended up living collectively for six years. During this time, they followed the peasants' uprising against the construction of Narita Airport throughout seven films, made from the viewpoint of farmers, between 1968 and 1973. ${ }^{13}$ They are the so-called Sanrizuka series, in which the weight of Hani's documentary school is evident in a number of traits, such as improvisation and the lack of scripts, but particularly in the familiarization with the lives of protagonists. Ogawa's team shared the farmers' lifestyle and concerns and the portrayed struggle became their own struggle. The film crew participated in the construction of barricades and joining the fight against the riot police-the cameraman Koshiro Otsu was even arrested during the shooting of A Summer in Narita (1968). The limits between the concepts of subject (shutai) and object (taisho), discussed by Nornes (2007), become increasingly blurred. Ogawa and his crew turned out to be inseparable elements of the filmed reality when the collective moved to Magino village in Yamagata Prefecture and ended up living as farmers for the following thirteen years while making documentaries about rural life.

\section{Hani's Method on Films of Landscapes}

\subsection{The Inner World of a Temple}

Going back to Hani's theoretical framework, he proposes a third possibility for exploring subjectivities alien to that of the filmmaker, temples (Hani 1958, pp. 158-213) or, in other words, architectural landscapes. But what kinds of inner world could be captured from an inanimate structure?

\footnotetext{
11 For an account on these lesser known works see Centeno Martí (2016, pp. 33-54).

12 Both, Ogawa and Tsuchimoto left Iwanami Eiga together with Hani in 1964 and became independent filmmakers.

13 For an extensive account on this film see Nornes (2007, pp. 54-128)
} 
This proposal of making films without ("living") characters becomes a courageous attempt to explore subjectivities in the 1950s documentary. Hani crystalises this idea in his enigmatic Hōryūji (1958), a middle-length film about the eponymous temple in Nara, the country's oldest wooden structure and a World Heritage Site since 1993. Surprisingly, the film keeps great consistency with Hani's method developed in his earlier works, including shooting on location, non-professional actors, rejection of scriptwriting, and adaptation to the changing circumstances of the environment, e.g., Hani and his cameraman Junichi Segawa took advantage of changes in natural light to capture different tints on the coloured wood as well as the reddish walls.

More than a decade before, the same temple had been filmed by Kenji Imamura in his documentary, Hōryüji (1943), which is depicted from outside to inside. However, Hani focuses on the interiors. His earlier scenes, shot in classrooms and zoo cages, are replaced with hidden corners in the temple. In addition, instead of children and animals, we find wooden sculptures, which are portrayed through a variety of camera angles and movements, making viewers forget that they are inanimate figures. Segawa's thorough camerawork depicts the temple by playing with lighting and volumes and experimenting with a long focus lens and different compositions. The camera reaches unseen details of the temple, revealing beautiful aspects of the figures, such as wood wear, traces of gold upon the sculptures, twists imitating clothes, veins in their hands, and wrinkles on their faces.

While Hōryūji was financially a failure (Kudō 2018), the film succeeded in exploring a new kind of subjective approach, giving the impression that the temple had come to life. Sato (2010) highlighted its ability to create the illusion of movement between the building shapes and structures. More recently, Tsutsui $(2012$, p. 73) pointed out that its brilliance was a result of the rhythmic montage that became a sort of poetic expression of the temple's energy. The existing accounts on this film share that impression. According to which, what is represented in Hōryüji goes beyond the physical appearance of the carved wooden figures. Hani reaches an internal dimension transcending the materiality of the filmed object. Editing becomes a mosaic of paintings, reliefs, and sculptures of demons, Buddhas, and old emperors, portrayed with a lyricism that provides the temple with a living and anthropomorphized nature. As Satō noted, "the content is full of multiple sentiments and human emotions hiding a sympathy towards sculptures that have virtually become men. Hōryūji is alive" (Satō 2010, p. 274). ${ }^{14}$

According to Hani, monks of the temple asked him to keep a respectful attitude towards those sacred figures and not to see them as simple objects (Hani 1958, p. 167). Hani certainly projects a special aura over the objects, however, he moves away from mere veneration. Above any religious belief, the sculptures on screen seem to be animate figures. The statuettes of musicians playing the flute seem to perform the piece composed by Akio Yashiro, which is simultaneously heard on screen. This cinematic phenomenon of using the soundtrack as a device to present a living temple gains prominence in the room, representing the Buddhist scene of Shūmisen or Mount Sumeru.

The jarring voices of torment are played by a choir over close-ups of disturbing faces sculpted with enigmatic expressions of ire, awe, and suffering. Thus, Hani finds unusual marks of subjectivity in the filmed environment, throughout which inanimate figures seem to invite viewers to an inner and mysterious world. The sculptures present a hidden universe that somehow was linked to the people that had carved them in the seventh century. The abundant extreme close-ups reveal a refined technique with which they had been created but also something about the spirit of those anonymous people who left upon wood messages about their fears, pleasures and desires. In this way, Hōry $\bar{u} j i$ presents an unusual display of emotions throughout these perturbing faces, which seem to contain the beliefs and daydreams of those who had built it.

14 Author's translation. 


\subsection{Humanising the Rural Landscape}

Hani had started exploring the depth of the filmic environment in his first work at Iwanami Eiga, a series of photographic reports on the country's prefectures, called Shin Fudoki (New Geographic Chronicle). It was published between 1954 and 1958 as a result of collaboration with the publisher Iwanami Shoten. A few years later, Hani directed the television documentary Gunma-ken 2 (broadcast on 27 May 1962). This was the 49th episode of Nihon Hakken [Discovering Japan], a series produced between 1961 and 1962, for which Tsuchimoto Noriaki and Ogawa Shinsuke had also worked. It was produced by Iwanami Eiga for NET channel and found inspiration in Shin Fudoki printed reports. In January 1962, Kuroki Kazuo made the first part of a documentary on Gunma prefecture and in May, Hani made the second part. This was a region that Hani knew well, as it was the homeland of his father and they summered there during his childhood (Hani 1973, p. 181). Gunma-ken 2 is based on the photographic report "Gunma ken", a volume published in 1956, whose editor was the renowned photographer Natori Yōnosuke.

According to Hani, this way of capturing reality proposed by Natori was opposed to his own. ${ }^{15}$ As a consequence, comparing Gunma ken 2 with Natori's "Gunma ken" becomes an enriching exercise to explore Hani's singular style in depicting landscapes. While Natori (1963, pp. 55-65) seeks a rational and even scientific description of landscapes, rejecting any ambiguity on images, Hani is not only interested in the physicality of the rural environment, but also in the people living in it. This difference materializes at the formal level too. Natori privileges middle and long shots, moving away from the human presence and focusing instead on its geography, and the characteristics of its rivers, mountains, wetlands, gardens, and hot springs. On the contrary, Hani makes wide use of close-ups and extreme close-ups and gives the landscape a subjective dimension through the interaction with its inhabitants. ${ }^{16}$ As Karatani Köjin asserted, the analysis of the landscape, which was discovered in Japan through European painting and photography in the 19th century, helped to produce an understanding that subject and object are not prior to the landscape, but emerge within it (Karatani 1993, p. 34). Thus, rather than a mere objective representation of its materiality, the landscape in Hani is only the result of the interactions with other subjects depicted in this external environment. The film evolves in relation to the weight and importance that the landscape has for the people living in it.

\subsection{Applying the Method to an Urban Landscape}

Hani participated in a cinematic experiment on the representation of landscape in Tokyo 1958. This is a collective film made alongside Teshigahara Hiroshi and the other seven members of the group Cinema 58. ${ }^{17}$ This work focuses on the urban space of Tokyo and was made in order to be sent to the Brussels World Fair of 1958 (Ogi 1958, p. 72). Tokyo 1958 is a documentary that is difficult to categorize. Each collaborator applied their personal gazes to portray the Japanese metropolis, resulting in a heterodox work comprised of an amalgam of styles and genres. The portrayal of Tokyo's geography begins with the representation of figures about its population, birth and death rates, and the number of cameras and cinemas per inhabitant. However, this expository format is quickly followed by a succession of satiric and humoristic experimentations employing overprints of $u k i y o-e$ engravings, sound effects taken from the classical Noh theatre, such as taiko, drums, and kakegoe, drummers' utterances, or classical music such as gagaku. Other scenes combine television reports and commercial formats with an avant-garde style, featuring eccentric camera angles, framing, and movements.

The material coexistence of diverse modern and premodern formats in the film also serves to highlight its main theme, the coexistence of modernity and tradition in the city. The filmmakers bring the viewer to Ginza district, where one finds a diverse depiction of the Japanese economic miracle,

15 Hani interview in Centeno Martín (2015, p. 774).

16 For examples on these differences between Hani and Natori's style see Centeno Martí (2016).

17 I have previously written a more detailed analysis of Tokyo 1958 in Centeno Martín (2019a, pp. 41-62). 
including boutiques that specialize in Shinto weddings as well as bustling department stores full of advertisements from the new cosmetic industry. Japanese modernity seems to have been "prettied up" as a false appearance. This urban space is represented as having been rebuilt by modern citizens who keep repeating folk practices, such as hatsumode, who visit Shinto shrine in New Year, and who keep consuming eroticism that can be traced back to the old shunga art of woodblock prints. The authors also find contradictions related to the endogamy of the economic and political structures in the Tokyo landscape where the elites, including the emperor, have perpetuated their power for centuries. The faces of businessmen and politicians are portrayed with premodern paintings of feudal figures.

\section{Impact on Subsequent Avant-Garde Documentaries}

\subsection{Recovering the Fascination for the Architectural Environment}

The aforementioned examples about films of landscapes illustrate a lesser known facet of Hani's documentary method, whose impact can be traced through disparate filmmakers such as Teshigahara and Adachi Masao. Hani's approach to documentary film clearly had a great impact on Teshigahara. He was exposed to Hani's practices through their activities as members of Kiroku Geijutsu no Kai from 1957 and their collaboration in Tokyo 1958. However, Teshigahara was also aware of Hani's theoretical developments and defended his stance before that represented by Matsumoto and Noda (see Hani et al. 1961; Matsumoto and Noda 1964).

Hani's impact is evident in a cinematic experiment Teshigahara embarked on only one year after filming Tokyo 1958, the documentary Antonio Guadi (1984), which focuses on the architectural landscape of Barcelona. Teshigahra travelled to Barcelona in 1959 to make a documentary on the buildings designed by the Catalan architect, Antonio Gaudí. He travelled to Spain together with his father, Sofu Teshigahara, a renowned ikebana master and filmed footage on $16 \mathrm{~mm}$ film, including a visit to Salvador Dali's home in Port Lligat village. ${ }^{18}$ The project was eventually abandoned, only to be taken up again by Teshigahara a quarter of a century later as a homage to his father, who had passed away a few years earlier. Thus, Teshigahara not only returns to the same city, but also revives the interest for renewing documentary cinema that had been developed in the 1950s. He draws on the discussion developed by the post-war cultural circles about the necessity of redefining the document through a "synthesis of arts" or sōgō geijutsu. The film combines scenes of modernist architecture created by Guadí with empty shots of Barcelona's Gothic Quarter, medieval frescos, Joan Miró's paintings and sculptures, and traditional dances performed at Spain Square.

Gaudí contains some black and white footage and photos that Teshigahara took in 1959 and shows this architectural landscape using a filmmaking method similar to that employed by Hani in Hōryūji temple. All sorts of technical resources, shot scales, and camera movements are deployed to capture the details of colour and shapes of Gaudís buildings. The same interest that Hani had in filming impossible corners of the temple is developed through close-ups featuring craftwork, glasses, mosaics, twisted shapes in windows, floors, ceilings, and columns. ${ }^{19}$

As was the case in Hōryūji, some high shots were taken from scaffolding and cranes, and it has been suggested that some of them may have even been filmed by operators lowering themselves using ropes (William 2009, p. 10). Another stylistic trope resembling Hani's Hōryūji is the entrance to the Casa Milà building through opening gates while the camera comes in and shoots the interior. Last but not least, similarly to Hōryūji, the soundtrack, composed by Toru Takemitsu alongside Kurodo Mori and Shinji Hori, plays a dominant role in Gaudi and, as has been noted (Holden 1998, p. 23), it contains a hypnotic power aimed at projecting fascination as well as bewilderment on the screen.

18 This footage Gaudi, Catalunya, 1959 has been edited recently in Criterion's DVD Hiroshi Teshigahara. Antonio Gaudí.

19 For a closer analysis of Gaudi see Centeno Martín (2019b). 


\subsection{Interrogating Japanese Enigmatic Landscapes}

The influence of Hai's exploration of inner universes hidden in the environment is not only visible in Teshigahara. One decade after Hani's Hōryūji, Masao Adachi recovered the interest in urban and rural landscapes through his enigmatic documentary film A.K.A. Serial Killer (Ryakusho: renzoku shasatsuma, 1969). This is another collective film made by Adachi and the members of the Nichidai Eiken film club at Nihon University. They follow thirty-three places in which the 19 year old boy Norio Nagayama lived before perpetrating multiple murders in 1969, for which he was sentenced to death. This case gained notoriety among intellectuals and artists and became a symbol against the death penalty in Japan. Nagayama had been born in poverty to a broken family in Hokkaido. As a young boy, he travelled and worked across the country until he stole a gun at the American military base in Yokosuka and killed two guards and two taxi drivers. Before being executed for these crimes, Nagayama spent three decades on death row where he learned to read and wrote several novels, including his autobiography Tears of Ignorance (Muchi no namida, 1971), donating any profits to the families of his victims. Kaneto Shindō adapted Nagayama's story for the big screen in Live Today, Die Tomorrow (Hadaka no jūkyūsai, 1970). However, Adachi and Nichidai Eiken members took a different approach and decided to focus on the relationship between this case and the landscape. As Furuhata (2007, p. 349) has explained, the film is closely linked to the fükeiron ("the theory of landscape") led by the film theorist Masao Matsuda, who had also participated in the film, from the late 1960s. The theory of landscape, in which Adachi had also participated, channeled a growing skepticism towards the prominence of the "subject" (shutai) and was accompanied by criticism of the documentary genre and political and aesthetical resistance to the commercial cinema of the time.

A.K.A. Serial Killer presents an unconventional experiment that echoes Hani's proposal of finding inner worlds hidden in the external world. The authors of the film invite the viewer to see Japan through the eyes of the murderer by exploring an internal dimension of the Japanese landscape that could explain the crime. Similar to Hani's stance, the scarce voice-over and lack of narrative structure shift the focus from the filmmaker to the profilmic world. In other words, the authorial subjectivity is replaced with that of the filmed environment. Adachi and his peers include sequences of factories, working-class neighborhoods, trains and markets, barely featuring people on screen, while those who are shown are mostly reduced to uniformed schoolchildren and the Self-Defense Forces. This portrayal becomes a claustrophobic and strangely homogeneous setting in which there is a strong presence of economic, political, and military structures of power (Matsuda 1971, p. 16).

\section{Conclusions}

Hani's films on landscapes and the theoretical discussions that have accompanied them since the 1950s constitute a fundamental cornerstone for understanding some of the most relevant aspects that characterised the documentary avant-garde in post-war Japan. Hani's contribution emerges from a context of ideological and aesthetical rupture among documentary makers, triggered by a growing interest in promoting subjective approaches to reality. Therefore Hōryūji comes to illustrate a singular kind of film, made with "protagonists who do not act". Hani proposes to interrogate an invisible but also authentic universe, free from filmmaker's prejudices. This reveals the applicability and consistency of Hani's documentary method in films featuring no characters, a topic that has not been studied to date.

Surprisingly, Hani finds inner universes existing in different kinds of landscapes, obtaining similar results to those of earlier documentaries on animals and children. He discovers that landscapes are a deep rather than a flat environment, in which cameras can penetrate and discover hidden realities. This is possible because the landscape is not a mere abstract space that merely projects author's perceptions, interests, and concerns. For Hani, it is rather a lived space that has been carved, shapped, inhabited, and even designed by other people, and the marks of these alien inner words are subject to be explored by filmmakers. These ideas are also articulated in discussions that undoubtedly reveal the existence of a rich theoretical production in Japan. Hani's theoretical and practical contributions 
mark the inception of a documentary school based on filmmakers' extraordinary engagement with the topics and characters they depicted. This filmmaking style was followed not only by Ogawa and Tsuchimoto's militant cinema, but was also adapted by filmmakers such as Teshigahara and Adachi, who were involved in making films on different kinds of architectural, rural, and urban landscapes. As a consequence, we should not assess all these directors as isolated authors since they became key figures of a true Documentary School in post-war Japan. They reconceptualized cinema with a groundbreaking approach to reality that raises fascinating questions about subjectivity, the engagement of filmmakers in the filmed reality, and authorship.

Thereby, the documentaries of landscapes assessed in this article constitute some of the most unusual and the boldest attempts to explore the possibilities of subjectivity in Japanese non-fiction and show how the documentary avant-garde of the time moved in multiple and unexpected directions. Through a close gaze deployed on the environment, Hani and subsequent filmmakers, such as Teshigahara and Adachi, reveal something intimate that trascends the materiality of the filmed objects. The examples demonstrate how documentary cinema is only partially limited by the materiality of the external world. They interrogate details that evoke a human presence which makes documentary film expand beyond the physical appearance of its objects.

Funding: I hugely appreciate the financial support provided by the Daiwa Foundation (ref: 197/13307) and GREGAL Research Project (SGR 2017-2019) particularly to its IP, Blai Guarné.

Acknowledgments: I am really grateful to Michael Raine for his enriching discussion on Matsumoto and Hani following Kinema Club Symposium at Sainsbury Institute in 2017 and for his extraordinarily effective work co-editing this special issue. I am also indebted to Iwanai Eizō, particularly to Michiko Nakai, for helping me find Hani's documentaries used in this article and Jinshi Fujii who, years ago, introduced me to the Kiroku Eiga Ākaibu Projekuto, whose seminars at Todai were extremely useful.

Conflicts of Interest: The author declares no conflict of interest.

\section{References}

Banouw, Erik. 1996. Documentary: A History of the Non-Fiction Film. Gedisa edition. Barcelona and Nueva York: Oxford University Press. First published 1974.

Centeno Martín, Marcos P. 2015. Susumu Hani (1950-1960): The Theoretical and Practical Contribution to the Japanese Documentary and Youth Cinema. An Approach to Hani's Case as a Precursor of the New Wave. Ph.D. thesis, Universitat de València, València, Spain.

Centeno Martí, Marcos P. 2016. Imágenes del «espíritu de reconstrucción». Hacia el redescubrimiento del documental japonés a través de la obra olvidada de Susumu Hani. In El Japón Contemporáneo. Una aproximación desde los Estudios Culturales. Edited by Lozano Artur. Barcelona: Ed. Bellaterra, pp. 33-54.

Centeno Martín, Marcos P. 2019a. Post-war Narratives through Avant-garde Documentary: Tokyo 1958. In Media and the Politics of Memory in Japan. Edited by Lozano Artur, Martínez Dolores and Guarné Blai. New York and Oxford: Berghahn Books, pp. 41-62.

Centeno Martín, Marcos P. 2019b. Crónicas de Paisaje. Nuevas formas de subjetividad en la vanguardia documental japonesa. In Memoria y paisaje en el cine japonés de posguerra. Edited by Pedro Iacobelli. Santiago de Chile: Pontificia Universidad Católica de Chile.

Furuhata, Yuriko. 2007. Returning to Actuality: Fūkeoron and the Landscape Film. Screen 48: 345-62. [CrossRef]

Gerow, Aaron, and Tsuchimoto Noriaki. 2014. Tsuchimoto Noriaki. Documentarists of Japan No. 7. Documentary Box. Available online: http://www.yidff.jp/docbox/8/box8-2.html (accessed on 5 April 2019).

Hani, Susumu, Donald Richie, Teizō Kanda, and Tatsuhiko Matsugi. 1956. Avan garudo eiga ni tsuite: Donald Richie shi ni kiku (On avant-garde: Asking Donald Richie). Eiga Geijutsu No. 6: 45-52.

Hani, Susumu, Noda Shinkichi, Matsumoto Toshio, and Teshigahara Hiroshi. 1961. Kiroku eiga to gekieiga. Dokyumentarī no hōhō o megutte (Documentary Film and Fiction Film. About the Documentary Method). Shin Nihon Bungaku 16: 125-37.

Hani, Susumu. 1956. Satsuei shinagara manabukoto (What One Learns While Shooting). Gunzō 11: 211-14.

Hani, Susumu. 1958. Engi shinai shuyakutachi (Protagonists Who Do Not Act). Tokyo: Chūō Kōronsha.

Hani, Susumu. 1959a. Zenei eiga no koto (On Avant-garde Film). Ongaku geijutsu No. 8: 69-70. 
Hani, Susumu. 1959b. Eizō de wa kangaerarenaika (Can't We Think With Images?). Mita bungaku 2: 47-50.

Hani, Susumu. 1960. Kamera to maiku (Camera and Mic). Tokyo: Chūō kōronsha.

Hani, Susumu. 1961a. Gendai pōrando no eiga (Contemporary Polish Cinema). Ongaku Geijutsu 19: $24-25$.

Hani, Susumu. 1961b. Teikō no enerugī to hiroizumu. Higashi yōroppa de kangaeta koto (2) (The Resistance's Heroism and Energy. What I Thought in Eastern Europe (2)). Chūō Kōron No. 3: 175-79.

Hani, Susumu. 1961c. Kenryoku to taiwa suru mono. Higashi yōroppa de kangaeta koto (3) (People Speaking with Power. What I Tought in Eastern Europe (3)). Chīo kōron No. 4: 53-261.

Hani, Susumu. 1963. Atarashi eiga (New Cinema). Scenario No. 1: 122-32.

Hani, Susumu. 1969. Bi no shisō (The Idea of Beauty). Edited by Hani Susumu. Tokyo: Chikuma shobō.

Hani, Susumu, and Fumio Kamei. 1957. kiroku eiga no uso to shinjhitsu (Truth and Lie in Documentary Fim). Kinema junpō 15: 40-47.

Hani, Susumu. 1959c. Gijutsu no ninmu (The Technique's Duty). Mita bungaku 49: 45-50.

Hani, Susumu. 1972. Ningenteki eizōron (Theory of Human Image). Tokyo: Chūō kōronsha.

Hani, Susumu. 1973. Boku ga dōbutsu ni mananda koto [Lo que aprendí de los animales]. Tokio: Bunka Shuppan kyoku. Holden, Stephen. 1998. Film Review: A Musical Tour of Architecture as an Ode to Fertility. New York Times, February 27, p. 23.

Iijima, Kōiji. 1960. Hani Susumu to 'Furyō shōnen' (Susumu Hani and Bad Boys). Eiga hihyō 17: 24-28.

Imamura, Taihei. 1940. Eiga kirokuron (Documentary Film Theory). In Kiroku eigaron. Tokyo: Daiichi Geibunsha, pp. 80-98.

Imamura, Taihei. 1952. Eiga no sekai (The World of Cinema). Tokyo: Shinhyōronsha.

Imamura, Taihei. 1954. Eiga riron nyūmon (Introduction to Film Theory). Tokyo: Itagaki Shoten.

Inoue, Miyo. 2019. The Ethics of Representation in Light of Minamata Disease: Tsuchimoto Noriaki and His Minamata Documentaries. Arts 8: 37. [CrossRef]

Iwamoto, Kenji. 1974. Nihon ni okeru montāju riron no shōkai (Introduction to Montage Theory about Japan). Hikaku bungakunenshi 10: 67-85.

Iwasaki, Akira. 1956. Kiroku eigaron (Theory of Documentary Film). Eiga hyōron 12: 26.

Jesty, Justin. 2019. Image Pragmatics and Film as a Lived Practice in the Documentary Work of Hani Susumu and Tsuchimoto Noriaki. Arts 8: 41. [CrossRef]

Karatani, Kōji. 1993. Origins of Modern Japanese Literature. Durham: Duke University Press.

Key, Margaret S. 2011. Truth from a Lie. Documentary, Detection and Reflexivity in Abe Kōbō's Realist Project. Lanham: Lexington Books.

Kudō, Mitsuru. 2018. Documentarists of Japan No. 10. Documentary Box. Available online: http://www.yidff.jp/ docbox/10/box10-2-e.html (accessed on 4 April 2018).

Matsuda, Masao. 1971. Fūkei no shimetsu (The Extinctionof Landscape). Tokyo: Tabata shoten.

Matsumoto, Toshio. 1963. Eizō no hakken. Avangyuarudo no dokyumentari. Tokyo: Seiryū Shuppan.

Matsumoto, Toshio. 2005. Zenei kiroku eigaron (Theory of Avant-garde Documentary). In Eizō no hakken. Avangyuarudo no dokyumentari. Tokyo: Seiryū Shuppan, pp. 59-61, Originally published in 1963, Tokyo: San'ichi Shobō.

Matsumoto, Toshio, and Shinkichi Noda. 1964. Sengo dokyumentarī eiga hensenshi V. Hani Susumu no kanōsei to sekai (History of the Transformations of postwar documentary film. V. The possibilities of Susumu Hani's World). In Kiroku to eizō. Tokyo: Eizō Geijutsu no Kai.

Natori, Yōnosuke. 1963. Shashin no yomikata,(The Way of Reading Photography). Tokyo: Iwanami Shoten.

Nornes, Abé Mark. 2006. El Rastro del cine documental japonés de posguerra: A tientas en la oscuridad. In El cine de los mil años. Una aproximación histórica y estética al cine documental japonés (1945-2005). Edited by Carlos Muguiro. Pamplona: Colección Punto de Vista.

Nornes, Abé Mark. 2007. Forest of Pressure: Ogawa Shinsuke and Postwar Japanese Documentary. Minneapolis: University of Minneapolis Press.

Ogi, Masahiro. 1958. 'Tōkyō 1958 to Shinema 58'. Eiga Hihyō 15: 72-74.

Raine, Michael. 2012. Introduction to Matsuoto Toshio: A Theory of Avant-Garde Documentary. Cinema Journal 51: 144-47. [CrossRef]

Satō, Tadao. 1970. Nihon eiga shisōshi (History of Japanese Cinema Ideas). Tokyo: Sanichishobō, pp. 373-74.

Satō, Tadao. 1971. Nūberu bāgu igo. Jjiyū o mezasu eiga (After the New Wave. Cinema Aspiring to Freedom). Tokyo: Chūōkōronsha. 
Satō, Tadao. 1973. Nihon eiga hyakusen. Tokyo: Akita Shoten.

Satō, Tadao. 1977. Nihon Kiroku Eizōshi (History of the Japanese Documentary Image). Tokyo: Hyōronsha.

Satō, Tadao. 1997. Hani Susumu. Geki eiga no kanosei wo kakudai shita ‘Furyō shōnen' (Susumu Hani. Bad Boys the film that expanded the possibilities of cinema"). In Nihon Eiga no Kysoshō tachi III. Tokyo: Gakuyō Shobō, pp. 3-12.

Satō, Tadao. 2010. Shirīzu Nihon no dokyumentarī [Series de cine documental japonés]. Tokio: Iwanami Shoten.

Toba, Kōji. 2010. 1950 nendai: 'Kiroku' no jidai (1950s: The Documentary Age). Tokyo: Kawade Shobō Shinsha.

Tsutsui, Takefumi. 2012. Nūveru vāgu toshite no Iwanami Eiga: Hani Susumu no sakuhin o chūshin ni (Iwanami Eiga as New Wave: Fosucing on Susumu Hani's oeuvre). In Iwanami Eiga no 1-oku furēmu (Images of Postwar Japan. The Documentary Films of Iwanami Productions). Edited by Niwa Yoshiyuki and Yoshimi Shunya. Tokyo: Tōkyō Daigaku Shuppankai, pp. 59-83.

William, Johnson. 2009. On Broadmindness. Film Quarterly 62: 10-12.

(C) 2019 by the author. Licensee MDPI, Basel, Switzerland. This article is an open access article distributed under the terms and conditions of the Creative Commons Attribution (CC BY) license (http://creativecommons.org/licenses/by/4.0/). 